\title{
Effects of overseeding times on different warm-season turfgrasses: Visual turf quality and some related characteristics
}

\author{
Sukru Sezgi Ozkan, Behcet Kir \\ Ege University, Faculty of Agriculture, Department of Field Crops, Izmir, Turkey
}

\begin{abstract}
Highlights
No gaps were formed in plots and high coverage degrees were maintained during overseeding periods in all treatments. Homogeneous spring transition was occurred from Lolium perenne L. to warm-season turfgrass species in all overseeding times. Visual turf quality performance of 6.0 scores and above which is acceptable level were obtained from all overseeding times. Better results were obtained from overseeding applications on Paspalum vaginatum and Cynodon dactylon $\times$ Cynodon transvaalensis. The different results among the warm-season turfgrass species can provide effective information for future research studies.
\end{abstract}

\begin{abstract}
The sustainability of warm-season turfgrass species in winter dormancy is a major concern in Mediterranean ecology. The concept of overseed a lawn has been still new for many developing countries such as Turkey as part of a regular maintenance. Therefore, a 2-year study was conducted at the experimental fields of Ege University, Izmir/Turkey during 2014-2016 years to compare the effects of four different overseeding times (September 15, September 30, October 15 and October 30) on four warm season turfgrass species (Cynodon dactylon cv. SR9554, Cynodon dactylon $\times$ Cynodon transvaalensis cv. Tifway-419, Paspalum vaginatum cv. Sea Spray and Zoysia japonica cv. Zenith) by measuring visual turf quality (1-9 score) and some related characteristics as texture (mm), cover (1-9 score), weed infestation (1-9 score) and colour ( $1-9$ score). ' $50 \%$ cv. Troya $+50 \%$ cv. Esquire' perennial
\end{abstract}

Correspondence: Sukru Sezgi Ozkan, Ege University, Faculty of Agriculture, Department of Field Crops, 35100, Izmir, Turkey.

E-mail: sukru.sezgi.ozkan@ege.edu.tr

Key words: Warm-season turfgrass; winter dormancy; Lolium perenne L.; overseeding; turf quality.

Acknowledgements and funding: Research study (2015-ZRF-026) founded by Scientific Research Projects Coordination of Ege University. This article is part of the corresponding author's $\mathrm{PhD}$ thesis.

Received for publication: 27 January 2021.

Revision received: 17 June 2021

Accepted for publication: 18 July 2021.

CC Copyright: the Author(s), 2021

Licensee PAGEPress, Italy

Italian Journal of Agronomy 2021; 16:1820

doi:10.4081/ija.2021.1820

This article is distributed under the terms of the Creative Commons Attribution Noncommercial License (by-nc 4.0) which permits any noncommercial use, distribution, and reproduction in any medium, provided the original author(s) and source are credited. ryegrass (Lolium perenne L.) mixture was used for overseeding in trial. According to results, visual turf quality performance of 6.0 scores and above were obtained from all treatments. We concluded that October 15 should be most suitable time for overseeding applications. Additionally, L. perenne L. can be practiced successfully in Mediterranean region in order to eliminate the concerns of warm-season turfgrasses in the winter dormancy period observed in cold temperatures.

\section{Introduction}

Humans and turfgrass are inextricably linked to each other (Thomasson, 1987). Turf areas are essential components of our modern and complicate life style. They have vital effects for balancing ecological and environmental aspects and enhance our life qualities (Demiroglu Topcu and Ozkan, 2016a). The recent global warming negative impacts on summer rainfall and water shortage in the Mediterranean region lead us to think about drought resistance of warm-season turfgrass species (Croce et al., 2001). Additionally, in the Mediterranean climatic conditions, warm-season turfgrass species are often preferred to cool-season turfgrass species due to their lower maintenance requirements (Giolo et al., 2019). These species generally require less water and are more drought tolerant and water-use efficient than others. Furthermore, growing warm-season turfgrass species in that area may result in supplemental benefits such as greater resistance to pathogens, enhanced tolerance to abiotic stressors (salinity, traffic, etc.) and better ability to compete with weeds (Schiavon and Baird, 2018; Giolo et al., 2019). However, when temperatures drop below $10^{\circ} \mathrm{C}$, warm-season turfgrass species enter dormancy and eventually leaves turn brown. Spring green-up occurs when soil temperatures persist for several days with an average above $10^{\circ} \mathrm{C}$ (Duble, 1996; Croce et al., 2004; Volterrani and Magni, 2004; Mirabile et al., 2016). Hence the loss of aesthetics and functionality during the cold winter months have hindered the widespread use of these species. Warm-season turfgrass species loss due to severe cold in transitional climates is a major concern (Ihtisham et al., 2018). To overcome this problem, warm-season turfgrass species are overseeded before the dormant winter months to provide year-round green turfgrass cover (Mazur and Wagner, 1987; Horgan and Yelverton, 2001). 
The practice of winter overseeding usually involves seeding a cool-season turfgrass into an established warm-season turfgrass canopy for temporarily restoring turf cover, colour, quality, playability, aesthetics, functional quality and overall performance during the dormant period (Horgan and Yelverton, 2001; Pompeiano et al., 2011). In addition, winter overseeding may occur positive impact on dormant warm-season turfgrass against weeds and traffic consequently and their disappear is prevented over the time (Horgan and Yelverton, 2001; Morris, 2004; Powell, 2005). Perennial ryegrass (Lolium perenne L.) traditionally has been the dominate turfgrass species used for overseeding into warm-season turfgrass in worldwide (Johnson, 1994; Horgan and Yelverton, 2001). Perennial ryegrass germinates rapidly (approximately 3-4 days), possesses dark green colour, and maintains desirable turf quality during winter months (Allen et al., 1993; Horgan and Yelverton, 2001).

Successful overseeding basically depends on various parameters as such as performance of turfgrass genotypes, maintenance and environmental conditions. The aim of our study was to evaluate the overseeding performances of bermuda grass (Cynodon dactylon), hybrid bermuda grass (Cynodon dactylon $\times$ Cynodon transvaalensis), seashore paspalum grass (Paspalum vaginatum) and zoysia grass (Zoysia japonica) by overseeding with perennial ryegrass (L. perenne $\mathrm{L}$.) and also to determine the most favourable overseeding periods in Mediterranean climate.

\section{Materials and methods}

\section{Site description}

A field experiment was carried out on mature (over 2 yearsold) warm-season turfgrass species at the agricultural experimental station of Field Crops Department, Agriculture Faculty, Ege University in Bornova/Izmir, western Turkey (38 27'05.76" N, 27'13'28.59" E and $26 \mathrm{~m}$ above sea level) during 2014-2016 years. The turf experimental area in Izmir has a typical Mediterranean ecological conditions. Some meteorological characteristics of the region during the experimental period and longterm (30 years) average are presented in Table 1. Typical Mediterranean climate was observed during the experimental years. Long-term average was $17.9^{\circ} \mathrm{C}$ at temperature and 685.1 $\mathrm{mm}$ at rainfall. It is observed that the amount of rainfall is irregular in different months. The soil structure and components of turf experimental area was loamy-sand (previously prepared for turf

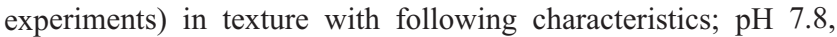
total $\mathrm{CaCO}_{3} 2.450 \mathrm{mg} \mathrm{kg}^{-1}$, total nitrogen $0.22 \mathrm{~g} \mathrm{~kg}^{-1}$, organic matter $2.439 \mathrm{~g} \mathrm{~kg}^{-1}$, available phosphorus $2.39 \mathrm{mg} \mathrm{kg}^{-1}$ and exchangeable potassium $127 \mathrm{mg} \mathrm{kg}^{-1}$.

\section{Experimental design and treatments}

The experimental design was in a split-plot design with three replications. The four warm-season turfgrass species $(C$. dactylon cv. SR9554 'Cd', C. dactylon $\times$ C. transvaalensis cv. Tifway-419 ' $C d \times C t$ ', $P$. vaginatum cv. Sea Spray ' $P v$ ' and $Z$. japonica cv. Zenith ' $Z j$ ') were main plots and four overseeding time treatments (September 15, September 30, October 15, October 30) were subplots. The subplot size was $1.8 \mathrm{~m}$ wide by $2.0 \mathrm{~m}$ long.

Prior to overseeding applications, warm-season turfgrass species were mowed and then verticutted in two directions and cleared of resulting debris. ' $50 \%$ cv. Troya $+50 \%$ cv. Esquire' perennial ryegrasses mix was used for overseeding at a rate of 75 $\mathrm{g} \mathrm{m}^{-2}$. Seeds of mixture were preweighed and the plots hand seeded at 15 day intervals beginning September 15 and continuing through October 30. Immediately after overseeding, plots were top-dressed with washed sand at $1.8 \mathrm{~kg} \mathrm{~m}^{-2}$ (Mazur and Rice, 1999 ) in order to speed up germination rate. Plots were seeded in two directions in order to ensure uniform distribution of perennial ryegrass mix seeds. Compound fertilizer was applied to the plots as primary fertilizer with $5 \mathrm{~g} \mathrm{~m}^{-2} \mathrm{~N}$ (Palm Organik; N-P-K: 12-1212 , natural humus $20 \%, \mathrm{Fe}, \mathrm{Zn}, \mathrm{Mn}$ ) in each overseeding times. The plots were mowed 2 weeks after overseeding at a cutting height of 4-5 cm, approximately. After establishment, the turf height was maintained at $2 \mathrm{~cm}$ for the duration of the research. Irrigation was applied to maintain optimum growth of perennial ryegrass when necessary (Grossi et al., 2008; Brilman, 2009). Slow release fertilizer was applied twice by calculating $10 \mathrm{~g} \mathrm{~m}^{-2} \mathrm{~N}$ (Azolon Turf Master; N-P-K:20-5-8, Mg 3\%, S 11.5\%) after the perennial ryegrass completely covered the plots and before the beginning of spring growth.

Considering the soil moisture, irrigation was continued regularly in spring and summer. Plots mowed regularly when the new shoots of the plants growth at the rate of $1 / 3-1 / 2$. In summer

Table 1. Some meteorological parameters in experimental area.

\begin{tabular}{|c|c|c|c|c|c|c|c|c|}
\hline \multirow{2}{*}{ Months } & \multicolumn{4}{|c|}{ Average temperature $\left({ }^{\circ} \mathrm{C}\right)$} & \multicolumn{4}{|c|}{ Total precipitation ( $\mathrm{mm}$ ) } \\
\hline & 2014 & 2015 & 2016 & LTA & 2014 & 2015 & 2016 & LTA \\
\hline January & 11.7 & 8.4 & 8.1 & 8.8 & 149.9 & 175.0 & 232.2 & 121.0 \\
\hline February & 11.7 & 8.9 & 13.9 & 9.5 & 14.8 & 100.9 & 85.1 & 101.9 \\
\hline March & 13.2 & 11.0 & 13.3 & 11.7 & 106.4 & 91.5 & 122.0 & 74.3 \\
\hline April & 16.7 & 14.2 & 19.0 & 15.8 & 132.2 & 31.4 & 28.4 & 47.0 \\
\hline May & 20.5 & 21.3 & 20.7 & 20.8 & 15.3 & 29.0 & 37.1 & 29.3 \\
\hline June & 24.7 & 23.6 & 27.5 & 25.6 & 48.5 & 52.3 & 2.8 & 8.3 \\
\hline July & 27.5 & 28.0 & 29.3 & 28.0 & 1.0 & 0.0 & 0.0 & 2.0 \\
\hline August & 28.1 & 28.4 & 28.9 & 27.6 & 3.8 & 35.6 & 0.4 & 2.2 \\
\hline September & 23.5 & 25.0 & 24.7 & 23.6 & 10.6 & 7.1 & 8.6 & 15.7 \\
\hline October & 18.4 & 19.2 & 19.5 & 18.8 & 91.1 & 83.5 & 0.5 & 44.3 \\
\hline November & 13.8 & 14.8 & 14.3 & 14.1 & 31.2 & 100.7 & 114.8 & 95.0 \\
\hline December & 11.8 & 9.0 & 8.3 & 10.5 & 249.3 & 0.0 & 20.2 & 144.1 \\
\hline$X-\Sigma$ & 18.5 & 17.7 & 19.0 & 17.9 & 854.1 & 707.0 & 652.1 & 685.1 \\
\hline
\end{tabular}

LTA, long-term average; X, mean; $\Sigma$, total. 
months (June, July, August) when the warm-season turfgrass species grow rapidly, slow release fertilizer (Azolon Turf Master; N-P-K: 20-5-8, Mg 3\%, S 11.5\%) was applied by calculating 10 gr $\mathrm{m}^{-2} \mathrm{~N}$. The plots were regularly sprayed with 15-day intervals using various fungicides (Maxim XL $035 \mathrm{FS}$, Tachigaren $30 \mathrm{~L}$ and Pomarsol Forte $80 \mathrm{WP}$ ) as a precaution against diseases that may be caused by humidity and high temperatures in the spring and summer months.

\section{Measurements}

The following measurements were maintained in the middle of every month during the overseeding periods (September-May) and means were obtained for each years. The visual turf quality was determined quantitatively by 'FieldScout GreenIndex+ Turf app and board' developed by Spectrum ${ }^{\circledR}$ Technologies, Inc. The primary output of GreenIndex+ Turf is an index (dark green colour index: DGCI) which quantifies the greenness of the turf and this index can be related to the visual rating of turf (Karcher and Richardson, 2003; Spectrum Technologies Inc., 2014). Visual ratings are a subjective method of assessing visual turf quality. They are based on a scale of 1 to 9 with $1=$ being poor and $9=$ being high quality (Morris, 2002). A rating of 6 or higher is typically considered to be acceptable turf quality (Morris and Shearman, 1998). A rating of 9 is assigned to ideal turf. Texture which is the measurement of the widest section of leaf blade was measured from samples of $L$. perenne L. with the help of an electronic caliper and described by millimeters (mm) according to Beard (1973) and Caskey (1982) scale. Turf cover and weed infestation values were assessed by a visual score based on a 1-9 scale (Beard, 1973; Caskey, 1982; Morris and Shearman, 1998). The colour values were also rated quantitatively using 'FieldScout TCM 500 Turf Colour Meter' developed by Spectrum ${ }^{\circledR}$ Technologies, Inc. based on a 1-9 scale (grass index) as used in NTEP Turfgrass Evaluation Guidelines (Morris and Shearman, 1998).

\section{Statistical analysis}

All data were statistically analysed using analysis of variance (ANOVA) with the Statistical Analysis System (SAS Institute, 1998). Both research years' values of the all characteristics were evaluated separately. Probabilities equal to or less than 0.05 were considered significant. If ANOVA indicated differences between treatment means a LSD test was performed to separate them (Stell et al., 1997).

\section{Results and discussion}

\section{Texture (mm)}

The turf texture findings are summarized in Table 2. Statistical analysis indicated that the effect of overseeding times and warmseason turfgrasses as well as $\mathrm{W} \times \mathrm{T}$ interaction were insignificant $(\mathrm{P}<0.05)$. Considering the values of our study, turf texture values were obtained between $2.8-2.9 \mathrm{~mm}$ in all practices. During the overseeding period (September-May), especially in the winter and spring seasons, mowing operations were carried out regularly in all plots simultaneously. For this reason, the new shoots of $L$. perenne plants in all plots showed similar growth rates after mowing operations.

\section{Cover (1-9 score)}

The statistical data related to turf cover were given in Table 2. According to data, there was a significant difference between the warm-season turfgrass species and the overseeding times in both years while $\mathrm{W} \times \mathrm{T}$ interaction was found insignificant $(\mathrm{P}<0.05)$. The best cover values were obtained from $P$. vaginatum plots in both research years (8.9 and 9.0 score, respectively) while the lowest cover value was recorded in Z japonica plots (8.1 and 8.2 score). On the other hand, the overseeding times were analysed statistically, the

Table 2. Effects of overseeding times on texture, cover, weed infestation, colour and visual turf quality of some warm-season turfgrass species.

\begin{tabular}{|c|c|c|c|c|c|c|c|c|c|c|}
\hline & $\begin{array}{r}\text { Tex } \\
\text { (I }\end{array}$ & & $\begin{array}{r}\text { Cov } \\
(1-9 \text { s }\end{array}$ & re) & $\begin{array}{l}\text { Weed } \\
(1-9\end{array}$ & $\begin{array}{l}\text { tation } \\
\text { e) }\end{array}$ & $\begin{array}{c}\text { Col } \\
(1-9\end{array}$ & re) & $\begin{array}{l}\text { Visual tu } \\
\text { (1-9 }\end{array}$ & $\begin{array}{l}\text { quality } \\
\text { ore) }\end{array}$ \\
\hline Warm-seasor & $\begin{array}{l}1 \text { st year } \\
\text { turfgra: }\end{array}$ & $\begin{array}{l}2^{\text {nd }} \text { year } \\
(W)\end{array}$ & $1^{\text {st }}$ year & $2^{\text {nd }}$ year & $1^{\text {st }}$ year & $2^{\text {nd }}$ year & $1^{\text {st }}$ year & $2^{\text {nd }}$ year & $1^{\text {st }}$ year & $2^{\text {nd }}$ year \\
\hline$C d$ & 2.9 & 2.8 & $8.3^{c}$ & $8.4^{\mathrm{c}}$ & $8.0^{\mathrm{b}}$ & $8.0^{\mathrm{b}}$ & 7.1 & $6.9^{\mathrm{b}}$ & $8.3^{c}$ & $8.2^{\mathrm{d}}$ \\
\hline$C d \times C t$ & 2.8 & 2.8 & $8.6^{\mathrm{b}}$ & $8.7^{\mathrm{b}}$ & $7.6^{\mathrm{c}}$ & $7.7^{\mathrm{c}}$ & 7.2 & $7.1^{\mathrm{a}}$ & $8.8^{\mathrm{a}}$ & $8.6^{\mathrm{b}}$ \\
\hline$P v$ & 2.9 & 2.8 & $8.9^{\mathrm{a}}$ & $9.0^{\mathrm{a}}$ & $8.3^{\mathrm{a}}$ & $8.4^{\mathrm{a}}$ & 7.1 & $7.0^{\mathrm{b}}$ & $8.9^{\mathrm{a}}$ & $8.8^{\mathrm{a}}$ \\
\hline$Z j$ & 2.9 & 2.8 & $8.1^{\mathrm{d}}$ & $8.2^{\mathrm{d}}$ & $7.4^{\mathrm{c}}$ & $7.5^{\mathrm{c}}$ & 7.2 & $7.0^{\mathrm{ab}}$ & $8.5^{b}$ & $8.4^{\mathrm{c}}$ \\
\hline Means & 2.9 & 2.8 & 8.5 & 8.6 & 7.8 & 7.9 & 7.2 & 7.0 & 8.6 & 8.5 \\
\hline Overseeding & times $(\mathrm{T}$ & & & & & & & & & \\
\hline September 15 & 2.9 & 2.8 & $8.1^{\mathrm{c}}$ & $8.3^{c}$ & $7.6^{\mathrm{c}}$ & $7.8^{\mathrm{c}}$ & $7.1^{\mathrm{b}}$ & $6.9^{\mathrm{b}}$ & $8.4^{\mathrm{c}}$ & $8.1^{\mathrm{c}}$ \\
\hline September 30 & 2.9 & 2.8 & $8.6^{\mathrm{ab}}$ & $8.7^{\mathrm{ab}}$ & $7.8^{\mathrm{bc}}$ & $7.8^{\mathrm{bc}}$ & $7.2^{\mathrm{ab}}$ & $7.0^{\mathrm{ab}}$ & $8.7^{\mathrm{b}}$ & $8.7^{\mathrm{a}}$ \\
\hline October 15 & 2.8 & 2.8 & $8.7^{\mathrm{a}}$ & $8.8^{\mathrm{a}}$ & $8.1^{\mathrm{a}}$ & $8.1^{\mathrm{a}}$ & $7.3^{\mathrm{a}}$ & $7.0^{\mathrm{a}}$ & $8.8^{\mathrm{a}}$ & $8.7^{\mathrm{a}}$ \\
\hline October 30 & 2.9 & 2.8 & $8.5^{b}$ & $8.6^{\mathrm{b}}$ & $7.9^{\mathrm{ab}}$ & $8.0^{\mathrm{ab}}$ & $7.2^{\mathrm{ab}}$ & $7.0^{\mathrm{a}}$ & $8.6^{\mathrm{b}}$ & $8.4^{\mathrm{b}}$ \\
\hline Means & 2.9 & 2.8 & 8.5 & 8.6 & 7.8 & 7.9 & 7.2 & 7.0 & 8.6 & 8.5 \\
\hline ANOVA & & & & & & & & & & \\
\hline W & ns & ns & $* *$ & $* *$ & $* *$ & $* *$ & ns & $*$ & $* *$ & $* *$ \\
\hline $\mathrm{T}$ & ns & ns & $* *$ & $* *$ & $* *$ & $*$ & $* *$ & $*$ & $* *$ & $* *$ \\
\hline $\mathrm{W} \times \mathrm{T}$ & ns & ns & ns & ns & ns & ns & ns & ns & ns & ns \\
\hline
\end{tabular}

$1^{\text {st }}$ Year: 2014-2015, $2^{\text {nd }}$ Year: 2015-2016. Cd, Cynodon dactylon; Ct, Cynodon transvaalensis; Pv, Paspalum vaginatum; Zj, Zoysia japonica; ANOVA, analysis of variance**: P< 0.01; *: P<0.05; ns: not significant. a-dMeans followed by different letters are significantly different $(\mathrm{P}<0.05)$ according to LSD's test. 
date of October 15 ranked best in the both research years.

Perennial ryegrass used in overseeding applications in our research is the most preferred cool-season turfgrass in turf areas both as a pure or as a mixture and for overseeding in the world (Ward et al., 1974; Beard, 2002). It has a uniform, medium texture, dense tillering and fibrous root structure and can be grown successfully in many different soil types. However, newly developed varieties are more tolerant of high temperatures than older varieties (Horgan and Yelverton, 2001; Fry and Huang, 2004; Yelverton, 2005). For this reason, they can rapidly germinate and dominate other species and disrupt the balance (Avcioglu, 1997) or because of their high competitive ability in overseeding applications in spring and early summer, they can negatively affect the turf quality during and after transition to warm-season turfgrass (Foy, 1998). The best values in terms of overseeding times were recorded on October 15 in both research periods. Schmidt and Blaser (1961) reported that overseeding on and after date of October 4 obtains better coverage results compared to overseeding performed on and before date of September 14. On the other hand, the best cover values in terms of warm-season turfgrasses were obtained in overseeding applications on $P$. vaginatum which emerged from dormancy with warming of the weather in spring and is known to have a very high competitive ability (Duble, 2000; Duncan and Carrow, 2000; Duncan and Carrow, 2005; Demiroglu Topcu and Ozkan, 2016b). Homogeneous transition was occurred between L. perenne which started to disappear with spring transition and $P$. vaginatum which increased in the environment. Therefore, it was concluded that no gaps were formed in plots and high coverage degrees were maintained during overseeding periods in all treatments.

\section{Weed infestation (1-9 score)}

Results of weed infestation were summarized in Table 2. According to statistical analysis, there was a significant difference between warm-season turfgrass species and overseeding times while $\mathrm{W} \times \mathrm{T}$ interaction was found to be insignificant $(\mathrm{P}<0.05)$. Similar results were observed in both research years. In our study, considering both research years, the best weed infestation values were determined from $P$. vaginatum plots ( 8.3 and 8.4 score) which has become highly popular in recent years in the world. The lowest weed infestation values were recorded from $Z$. japonica and $C$. dactylon $\times$ C. transvaalensis plots in both research years, respectively. In terms of overseeding times, the best scores were determined from overseeding applications on October 15 although the lowest values were obtained from overseeding applications on September 15 in both research years.

Our findings in this part of the study showed that all plots contained very small amounts or within acceptable limits weeds in terms of warm season turfgrasses and overseeding times factors. It is thought that these high weed infestation values are obtained due to very good cover values. The best cover values were obtained from overseeding applications applied on $P$. vaginatum which has a very high competitive ability (Duble, 2000; Duncan and Carrow, 2000; Duncan and Carrow, 2005; Demiroglu Topcu and Ozkan, 2016b). Perennial ryegrass used in overseeding applications showed superior growth during germination and then during the winter season due to sowing at optimum growth temperatures. Therefore, weeds could not find suitable growth environment in all treatments during both research periods and the best weed infestation values were obtained on October 15 overseeding time. Our findings are in agreement with the researchers who reported that turfgrass species which can exhibit superior features in competition with weeds do not allow weeds to grow in their environments and form a satisfying green cover (Beard, 1973; Uzun, 1992, Avcioglu, 1997; Christians, 1998).

\section{Colour (1-9 score)}

Our findings regarding turf colour are summarized in Table 2. Statistical analysis showed that there were no significant differences in first research year between main plant warm-season turfgrass species in terms of turf colour $(\mathrm{P}<0.05)$. This phenomena was not observed in second research year. There was significant difference in overseeding time factor in both years. On the other hand, $\mathrm{W} \times \mathrm{T}$ interaction was found insignificant both years. The best colour score was obtained from overseeding on $C$. dactylon $\times C$. transvaalensis plots while the lowest value was obtained from overseeding on C. dactylon plots. According to overseeding times, the dates of October 15, October 30 and September 30 ranked first, second and third, respectively. The lowest colour values were recorded from September 15.

Although colour is not agriculturally important in plants, it is a highly desirable feature visually in turf areas besides agronomic and physiological purposes (Kroon and Knops, 1990; Willems et al., 1993). Colour is a major component of the aesthetic quality of turf and often evaluated in field studies (Karcher and Richardson, 2003). Colour is directly related to the green colour and darkening tone, which symbolizes the external appearance of the turf areas and especially their aesthetic structure, resulting from the amount of chlorophyll that plants have biologically (Beard, 1973; Erekul and Avcioglu, 1995; Avcioglu, 1997). The development of warmseason turfgrass species slows down when the air temperature decreases below $15^{\circ} \mathrm{C}$ and stops completely if it is below $10^{\circ} \mathrm{C}$ (Duble, 1996). Dormancy, which occurs as yellowing in winter in these species, is the result of cessation of plant growth and breakdown of chlorophyll molecules in cells. Only the growing points in the nodes of the stolons and rhizomes survive through the winter by protecting themselves. With the temperature rising above $10^{\circ} \mathrm{C}$ again, warm-season turfgrass species provide the formation of green tissue again (Beard, 1973; Acikgoz, 1994; Avcioglu, 1997). L. perenne L. is widely used in overseeding applications especially in golf courses due to its cold resistance, high tolerance to wear, resistance to diseases and pests (Duble, 1996; Beard, 2002). According to a scale of 1-9 score, the average colour values obtained from the measurements at different dates during both overseeding periods varies between 6.9 and 7.3 score. It is thought that these colour value differences are due to the different colour values of the warm-season turfgrass species used in overseeding application. These differences were especially due to the autumn and spring transition periods when they are seen with L. perenne L. together in the environment. In addition, higher colour values were obtained in overseeding applications on September 30 and later since perennial ryegrass used in overseeding are allowed to grow at optimum growth and development temperatures due to their seeding in ideal climatic conditions.

\section{Visual turf quality (1-9 score)}

Visual turf quality results are summarized in Table 2. According to statistical analysis, $\mathrm{W} \times \mathrm{T}$ interaction was found insignificant in both research years while significant differences were also found between warm-season turfgrass species and overseeding times $(\mathrm{P}<0.05)$. The best visual turf quality values were obtained from $P$. vaginatum and $C$. dactylon $\times C$. transvaalensis plots while the lowest values were recorded from $C$. dactylon plots. According to overseeding times, the best visual turf quality values were determined from overseeding applications on October 15 and September 30 although the lowest values were obtained from overseeding applications on September 15.

The visual turf quality as the composite of colour, uniformity and weed infestation is a widely used criterion to define the overall performances of turfs in management practices (Avcioglu, 1997; 
Grossi et al., 2004; Demiroglu et al., 2010; Demiroglu et al., 2011; Ozkan et al., 2014; Kir et al., 2019). In the scoring of turf quality, besides uniformity, colour, cover and weed infestation characters, another feature to be considered is texture (fine-coarse) (Watschke and Schimidt, 1992; Croce et al., 2001; Volterrani and Magni, 2004; Zhou and Abaraha, 2007). In addition to these characters in overseeding applications, fall and spring transition characteristics of turfgrass area are also very important (Johnson, 1998; Horgan and Yelverton, 2001; Beard, 2002; Yelverton, 2005; Askew, 2010). In general, it is suggested by many researchers that the visual turf quality is varies greatly depending on the region where overseeding is performed, soil and climatic conditions and especially the species used (Longer, 2000; Grossi et al., 2008).

The results of the measurements performed with FieldScout GreenIndex+ Turf app and board showed that all examined overseeded warm-season turfgrass species had visual turf quality of 6.0 scores and above (Morris and Shearman, 1998), which is an acceptable quality level, at all overseeding times. It is considered that the differences between warm-season turfgrass species are due to their own different features while the differences between overseeding times are due to different growth and development of $L$. perenne L. in temperature differences among overseeding times.

\section{Conclusions}

The results of this study demonstrated that all warm-season turfgrass species and all overseeding times were obtained visual turf quality performance of 6.0 scores and above which is acceptable level. It is thought that the differences between the warm-season turfgrass species are due to their own different characteristics. While the best turf cover and weed infestation values were obtained from overseeding applications on $P$. vaginatum which is known to have a high competitive ability, the best turf colour values were determined from overseeding applications on $C$. dactylon $\times C$. transvaalensis. During the overseeding period in both years, especially in the winter and spring season, new shoots of $L$. perenne $\mathrm{L}$. grew at a similar rate due to the regular repetition of moving processes and therefore similar texture values were obtained from all treatments in our study.

In terms of visual turf quality and related characteristics examined in our research, we revealed that the best overseeding time was October 15 due to the drastic decrease in competitive capacity of all warm-season turfgrass species and existing physical-environmental conditions for germination and growth of perennial ryegrass.

\section{References}

Acikgoz E, 1994. Turf establishment and maintenance technique. Bursa Uludag University Press. [in Turkish].

Allen PS, White DB, Markhart III AH, 1993. Germination of perennial ryegrass and annual bluegrass seeds subjected to hydration-dehydration cycles. Crop Science 33:1020-25.

Askew S, 2010. Perennial ryegrass competition affects bermudagrass health. Golf Course Manage. 78:96-102.

Avcioglu R, 1997. Turf technique (turf establishment \& management). Ege University Press, Izmir, Turkey. [in Turkish].

Beard JB, 1973. Turfgrass Science and culture. Englewood Cliffs, N.J., Printice Hall, London, UK.

Beard JB, 2002. Turf management for golf courses, second edition. Ann Arbor Press, Chelsea, MI, USA.
Brilman LA, 2009. How to overseed dormant bermudagrass. TurfONE August 2009, pp 2.

Caskey MM, 1982. Lawns and ground covers. Horticultural Publishing Co. Inc., Tuscon, pp 135.

Christians NE, 1998. Fundamentals of turfgrass management. Ann Arbor Press, Chelsea, MI, USA.

Croce P, De Luca A, Mocioni M, Volterrani M, Beard JB, 2004. Adaptability of warm season turfgrass species and cultivars in a Mediterranean climate. Acta Hortic. 661:365-8.

Croce P, De Luca A, Mocioni M, Volterrani M, Beard JB, 2001. Warm-season turfgrass species and cultivar characterizations for a Mediterranean climate. Int. Turfgrass Soc. Res. 9:855-9.

Demiroglu Topcu G, Ozkan SS, 2016a. Turf ecology. pp 63 in Abstract Book of the International Ecology 2016 Adnan Aldemir Symposium, 16-19 May, Kars, Turkey.

Demiroglu Topcu G, Ozkan SS, 2016b. A Turfgrass alternative that may be the solution for salinity 'Paspalum vaginatum Swartz'. pp 3419-3423 in Full Text Book of the 1st International Academic Research Congress, 3-5 November, Antalya, Turkey.

Demiroglu G, Avcioglu R, Kir B, Salman A, 2011. Investigations on texture weed invasion and density features of some cool season turf grass cultivars in Mediterranean environment. Int. J. Agric. Biol. 13:461-8.

Demiroglu G, Geren H, Kir B, Avcioglu R, 2010. Performances of some cool season turfgrass cultivars in Mediterranean environment: II, Festuca arundinaceae Schreb., Festuca ovina L., Festuca rubra spp. rubra L., Festuca rubra spp. trichophylla Gaud and Festuca rubra spp. commutata Gaud. Turk. J. Field Crops 15:180-7.

Duble RL, 1996. Turfgrasses: their management and use in the Southern zone, second edition. Texas A\&M University Press, College Station, TX, USA, pp 1-323.

Duble RL, 2000. Seashore Paspalum, extension turfgrass specialist, Texas Agricultural Extension Service, College Station, TX, USA.

Duncan RR, Carrow RN, 2000. Seashore Paspalum: the environmental turfgrass. Ann Arbor Press, Chelsea, MI, USA.

Duncan RR, Carrow RN, 2005. Managing seashore Paspalum greens. Golf Course Manage. 73:114-8.

Erekul O, Avcioglu R, 1995. A research on techniques of elimination of winter yellowing in turf areas by overseeding. Ege University Graduate School of Natural and Applied Science, Master's Thesis, Izmir, Turkey. [In Turkish].

Foy JH, 1998. The pros and cons of fairway overseeding. USGA Green Section Record 36:10-12.

Fry J, Huang B, 2004. Applied turfgrass science and physiology. John Wiley and Sons, Hoboken, NJ, USA, pp 277.

Giolo M, Benincasa P, Anastasi G, Macolino S, Onofri A, 2019. Effects of sub-optimal temperatures on seed germination of three warm-season turfgrasses with perspective of cultivation in transition zones. Agronomy 9:421.

Grossi N, Volterrani M, Gaetani M., Lulli F, Magni S, Croce P, De Luca A, Mocioni M, 2008. Bermudagrass putting green overseeding with cool season turfgrasses in Coastal Tuscany. pp 87-88 in Proc. of the 1st European Turfgrass Society Conference, 19-20 May, Pisa, Italy.

Grossi N, Volterrani M, Magni S, Miele S, 2004. Tall fescue turf quality and soccer playing characteristics as affected by moving height. 1st International Conference on Turfgrass management and science for sports fields, Acta Hort. 661:319-22.

Horgan BP, Yelverton FH, 2001. Removal of perennial ryegrass from overseeded bermudagrass using cultural methods, Crop Science 41:118-26.

Ihtisham M, Fahad S, Luo T, Larkin RM, Yin S, Chen L, 2018. 
Optimization of nitrogen, phosphorus, and potassium fertilization rates for overseeded perennial ryegrass turf on dormant bermudagrass in a transitional climate. Front. Plant Sci. 9:487.

Johnson BJ, 1994. Fenarimol tolerance of roughstalk bluegrass overseeded in bermudagrass greens. Agronomy 86:519-522.

Johnson BJ, 1998. Influence of spring-applied herbicides on bermudagrass (Cynodon dactylon) greens overseeded with roughstalk bluegrass (Poa trivialis). Weed Technol. 12:1-6.

Karcher DE, Richardson MD, 2003. Quantifying turfgrass colour using digital image analysis. Crop Sci. 43:943-51.

Kir B, Avcioglu R, Salman A, Ozkan SS, 2019. Turf and playing quality traits of some new turfgrass alternatives in a Mediterranean environment. Turk. J. Field Crops 24:7-11.

Kroon D, Knops J, 1990. Habitat exploration through morphological plasticity in two chalk grassland perennials. Oikos 59:39-49.

Longer DE, 2000. Green winter colour for warm season lawns from overseeding with cool season species. TurfGrass Trends September, pp 12-15.

Mazur AR, Wagner DF, 1987. Influence of aeration, topdressing, and vertical mowing on overseeded bermudagrass putting green turf. HortSci. 22:1276-8.

Mazur AR, Rice JS, 1999. Impact of overseeding bermudagrass with various amounts of perennial ryegrass for winter putting turf. HortSci. 34:864-6.

Mirabile M, Bretzel F, Gaetani M, Lulli F, Volterrani M, 2016. Improving aesthetic and diversity of bermudagrass lawn in its dormancy period. Urban Fores \& Urban Green. 18:190-7.

Morris KN, 2002. A guide to NTEP turfgrass ratings. National Turfgrass Evaluation Program (NTEP), Beltsville, MD, USA.

Morris KN, Shearman RC, 1998. NTEP turfgrass evaluation guidelines. In NTEP Turfgrass Evaluation Workshop, Beltsville, MD, USA, pp 5.

Morris KN, 2004. Perennial ryegrasses fare well in overseeding of bermudagrass fairways. Turfgrass Trends December, pp 63-70.

Ozkan SS, Kir B, Avcioglu R, 2014. Effect of mowing heights on the performances of some turf alternatives in Mediterranean ecology. pp 337-340 in Proceeding Book of the 24th International Scientific-Expert Conference of Agriculture and Food Industry, 25-27 September, Cesme, Turkey.

Pompeiano A, Guglielminetti L, Volterrani M, 2011. Freeze tolerance of Zoysia matrella (L.) Merrill as affected by late-season nitrogen application, and changes in carbohydrates during cold acclimation. Plant Biosyst. 145:885-92.

Powell AJ, 2005. Overseeding bermudagrass sports fields.
University of Kentucky Extension, pp 5.

SAS Institute, 1998. INC SAS/STAT user's guide release 7.0, Cary, NC, USA.

Schiavon M, Baird JH, 2018. Evaluation of products to alleviate irrigation salinity stress on bermudagrass turf. Agronomy 110:2136-41.

Schmidt RE, Blaser RE, 1961. Winter Greens a Symposium: Part III: Overseeding in The Mid-Atlantic. USGA J. Turf Manage. 14:25-9.

Spectrum Technologies Inc., 2014. Fieldscout GreenIndex+ Turf Product Manual, Item \#2910TA, 2910T. Spectrum Technologies Inc., Aurora, IL, USA.

Stell RGD, Torrie JA, Dickey DA, 1997. Principles and procedures of statistics. A. Biometrical approach 3rd Ed. Mc Graw Hill Book, Inc., NY, USA.

Thomasson JR, 1987. Fossil grasses: 1820-1986 and beyond. In T.R. Soderstrom, K.W. Hilu, C.S. Campbell \& M.E. Barkworth (Eds.), Grass systematics and evolution. Smithsonian Institution Press, Washington, DC, USA, pp 159-167.

Uzun G, 1992. Lawn and sports field construction in landscape architecture. Cukurova University Agriculture Faculty, Supplementary Textbook No. 20, pp 170. [In Turkish].

Volterrani M, Magni S, 2004. Species and growing media for sports turfs in Mediterranean area, I International Conference on Turfgrass Management and Science for Sports Fields. ISHS Acta Hortic. 661.

Ward CY, McWhirter EL, Thompson WR, 1974. Evaluation of coolseason turf species and planting techniques for overseeding bermudagrass golf greens. pp 480-495 in E.C. Roberts (Ed.), Proc. Second Int. Turf Res Conf., Blacksburg, W.V., Amer. Soc. Agron., Madison, WI, USA.

Watschke TL, Schmidt RE, 1992. Ecological aspects of turf communities. In Waddington, D.V., Carrow, R.N. and Shearman, C.R. (Eds.), Turfgrass. American Society of Agronomy, WI, USA; Agronomy No. 32, pp 129-174.

Willems JH, Peet RK, Bik L, 1993. Changes in chalk-grassland structure and species richness resulting from selective nutrient additions. J. Vegetation Sci. 4:203-12.

Yelverton F, 2005. Spring transition: going, going, gone. United States Golf Association, Greens Section Record, March-April.

Zhou S, Abaraha A, 2007. Response to heat stress in warm season and cool season turf grass cultivars. Sci. Res. Essays 2:95-100. 